\title{
Mapping wave set-up near a complex geometric urban coastline
}

\author{
T. Soomere ${ }^{1,2}$, K. Pindsoo ${ }^{1}$, S. R. Bishop ${ }^{3}$, A. Käärd ${ }^{4}$, and A. Valdmann ${ }^{4}$ \\ ${ }^{1}$ Institute of Cybernetics at Tallinn University of Technology, Tallinn, Estonia \\ ${ }^{2}$ Estonian Academy of Sciences, Tallinn, Estonia \\ ${ }^{3}$ Mathematics Department, University College London, London, UK \\ ${ }^{4}$ Municipal Engineering Services Department, Tallinn, Estonia \\ Correspondence to: T. Soomere (soomere@cs.ioc.ee)
}

Received: 3 April 2013 - Published in Nat. Hazards Earth Syst. Sci. Discuss.: 24 April 2013

Revised: 9 September 2013 - Accepted: 24 October 2013 - Published: 29 November 2013

\begin{abstract}
Wave induced set-up is a process that leads to increased water levels in coastal regions. When coupled with storm conditions, wave set-up - or, for brevity, set-up - can significantly increase the risk of flooding or structural damage and therefore is of particular importance when considering coastal management or issues related to the planning of nearshore infrastructures. Here, we investigate the effects of set-up in the coastal region of the Gulf of Finland in the Baltic Sea, close to Tallinn, Estonia, although the results will have wider relevance for many other areas. Due to a lack of continuous wave data we employ modelling to provide input data using a calculation scheme based on a high-resolution $(470 \mathrm{~m})$ spectral wave model WAM to replicate spatial patterns of wave properties based on high-quality, instrumentmeasured wind data from the neighbourhood of the study site. The results indicate that for the specific geometry of coastline under consideration, there is a variation in set-up which is strongly affected by wind direction. The maximum set-up values are up to $70-80 \mathrm{~cm}$ in selected locations. This is more than $50 \%$ of the all-time maximum water level and thus may serve as a substantial source of marine hazard for several low-lying regions around the city. Wind directions during storms have changed in recent years and, with climate variability potentially increasing, these results will encourage further tests which may be used in a policy setting regarding defences or other structures in and around coastlines. In particular, with urban development now taking place in many coastal regions (including the one within this study) these results have implications for local planners. They may also be incorporated into new storm warning systems.
\end{abstract}

\section{Introduction}

Worldwide, cities are faced with the challenge of adapting to the effects of climate change. The interaction of the synergies and conflicts in the objectives of mitigation and adaptation are most vivid in urban areas, where they play out through land use, infrastructure systems, and the built environment (e.g. Hall et al., 2010). This interaction becomes even sharper, for coastal cities for which the collection of marine hazards and especially the risk of coastal flooding may be radically amplified by the potential influence of future global climate changes (e.g. as reported in Cheng et al., 2013; O'Grady and McInnes, 2010; Torresan et al., 2012; among many others).

Dangerous water levels are normally produced by an unfortunate combination of high tide, low atmospheric pressure, strong wind-driven surge of seas as well as waveinduced set-up. While usually the wind surge and inverted barometric effect (customarily called storm surge together) lead to the majority of the elevated water levels, wave set-up can contribute substantially under certain conditions.

It is well known that even almost linear ocean waves produce a mass transport that is proportional to the squared wave height (Starr, 1947), which is an example of so-called second-order effects. The propagation of such waves results in a decrease in the average water level (set-down) in areas of finite depth (Dean and Dalrymple, 1991). For waves approaching a coast, the water level minimum occurs at the seaward border of the surf zone.

As opposed to wave set-down, wave-driven set-up is a strongly non-linear phenomenon within the surf zone. It results in a rise in the mean water level in the nearshore owing 
to the release of momentum in the process of waves breaking. Theoretically, wave set-up can be quantified in terms of changes to the onshore component of the radiation stress (Longuet-Higgins and Stewart, 1964).

The prediction of wave set-up, and/or the quantification of its magnitude, is crucial during extreme events because its impact adds to other factors producing a high water level. To protect life and property, advance warning and detailed knowledge of wave set-up are vital in the design of coastal and nearshore structures vulnerable to high waves and water levels.

As yet, there is no consensus about the exact relationship between the offshore wave properties and the parameters of wave set-up (Hsu et al., 2006; Shi and Kirby, 2008; Nayak et al., 2012). Relevant estimates diverge radically (Stockdon et al., 2006), probably because the conversion of wave-driven momentum is very sensitive with respect to a multitude of factors. On the one hand, the properties of set-up substantially depend on the nature of the bottom (Apotsos et al., 2007). There is theoretical evidence that the set-up height may even be negative in the presence of vegetation and/or very rough bottom on the seabed (Dean and Bender, 2006). This is perhaps why users of the SWAN model broadly believe that the set-up height is in the range of $10-15 \%$ of the offshore wave height (Filipot and Cheung, 2012; Nayak et al., 2012). On the other hand, in particular conditions, the set-up may reach about $1 / 3$ of the offshore wave height (Vetter et al., 2010), and extreme values of set-up up to $2 \mathrm{~m}$ above the offshore water level have been observed being influenced by large storm waves (Heidarzadeh et al., 2009). A subtle but important impact of wave set-up under very rough seas is an increase in the water level at the entrance of wave-dominated inlets or lagoons (Bertin et al., 2009; Irish and Canizares, 2009; Torres-Freyermuth et al., 2012), a process that may considerably enhance the dangers, e.g. in the "aqua alta" in Venice (L. Cavaleri, personal communication, 2010).

Wave set-up is thus one of the core marine-induced hazards along many of our coasts. Its importance is relatively large at steep coasts with limited tidal range, where people are used to a more moderate range of variation in the water level. For example, in Florida wave set-up can be $30 \%$ to $60 \%$ of the total $100 \mathrm{yr}$ storm surge (Dean and Bender, 2006). In areas with relatively narrow continental shelves (more generally, in regions where the wind surge remains moderate) wave set-up can be an even larger contributor to extreme water levels during major storms (Dean and Bender, 2006). A natural reflection of this situation is the trend to include the analysis of the potential of wave set-up into various methods of the mapping of flood hazards for low-lying coastal regions (see Cariolet and Suanez, 2009; Harper et al., 2009; Jain et al., 2010a, b; among many others), especially in the context of potential changes in climate (McInnes et al., 2009) and for the purposes of estimates of the erosion of higher parts of the beach (Trenhaile, 2009).
While the properties of set-up are apparently more or less homogeneous and relatively easy to predict on long, basically straight, coastal sections, for coasts with complicated geometry this process has the potential to create unexpectedly high water levels in specific locations where storm waves directly approach the coast. As each storm may have a somewhat different wind direction, and the transformation of wave direction in the nearshore also depends on the wave periods, the most dangerous locations may vary considerably from one storm to another. (Note that, when describing wind properties, the wind direction is given by the direction from which the wind originates, but wave direction is usually given as the direction in which the waves propagate; thus an easterly wind produces a westerly wave). For city planning purposes, or estimates of the maximum inundation etc., this complicates the estimation of the maximum water level along coastal stretches with complicated geometry (Valdmann et al., 2008). In particular, this requires the use of a long-time climatology of wave properties to properly resolve effects caused by the directional distribution of the wave approach direction for different storms.

This problem is very acute in micro-tidal, semi-enclosed seas and shelf seas that are vulnerable not only to the potential increase in the overall water level but also to changes in the wave approach directions that have been recently identified for several regions (Räämet et al., 2010; Charles et al., 2012b). The problem is furthermore complicated in urban areas where flooding represents a particular challenge to modellers and flood risk managers because of the complex interactions of surface and sewer flows since, in practice, urban flooding systems involve tens of thousands of variables (Dawson et al., 2008).

The study area of the current paper is Tallinn Bay (Fig. 1), in Estonia. This area, similarly to the entire Baltic Sea, is micro-tidal (tidal range less than $5 \mathrm{~cm}$ ) and water level fluctuations are mostly governed by atmospheric forcing. As the predominant wind direction is from the south-west, and the city is located at the southern coast of the Gulf of Finland, the coasts of the urban area are implicitly sheltered from the most furious wave storms in this area. This feature is reflected in the relatively modest all-time maximum water level $(1.52 \mathrm{~m})$ since the end of the 19th century, whereas Saint Petersburg, for example, has experienced flooding heights up to $4.21 \mathrm{~m}$ and Pärnu $2.75 \mathrm{~m}$ (Suursaar et al., 2006). In Tallinn, some parts of the city are not protected even against a moderate water level rise. For example, when the water level rose to $1.52 \mathrm{~m}$ on 8-9 January 2005 , several low-lying areas (such as the 1980 Olympic sailing centre) were flooded. Typically water levels in this area are about $0.7-0.9 \mathrm{~m}$ above the long-term mean during several weeks in the autumn stormy season. As the critical water level of several infrastructure facilities of the city of Tallinn is about $1 \mathrm{~m}$, even a moderate wave set-up, say, about $0.5 \mathrm{~m}$, may lead to serious consequences. 


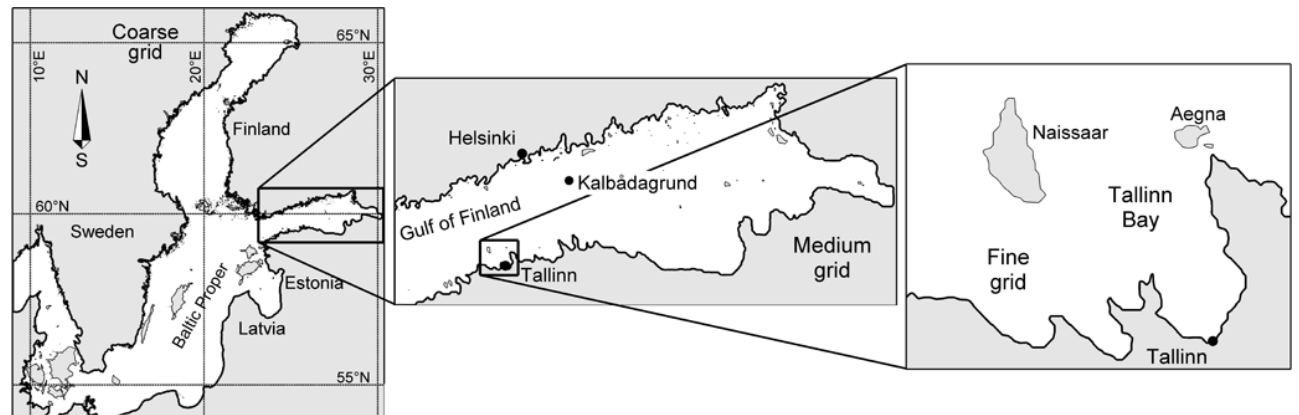

Fig. 1. Computational areas of the triple-nested wave model applied to the Tallinn Bay area.

The situation along the coastline of the entire urban area of Tallinn is even more complicated because of the particular geometry of Tallinn Bay and its neighbouring small bays. The three largest bays, Tallinn Bay itself, Kopli Bay and Kakumäe Bay to the west, are open to the north-west or north-north-west (NNW). Winds from these directions are somewhat less frequent than south-western winds but contain the strongest winds in the north-eastern part of the Baltic (Soomere, 2001). While the coasts of the interior of Tallinn Bay are relatively well protected, beaches at the bayheads of the two other bays and along the Viimsi Peninsula have an open shape, and many stretches possess the features that are favourable for producing high set-up adjacent to low-lying existing and planned residential areas.

The study area chosen here is an example of a wavedominated micro-tidal coastline which is locally almost straight (for scales up to few 100s of metres or, at some locations, up to a kilometre or two), but on larger scales (from a few kilometres) the coast contains large peninsulas and bays deeply cut into the mainland. In essence, this is a relatively young coast which is actively in the process of straightening (Raukas and Hyvärinen, 1992). The process of wave set-up crucially depends on the wave height and propagation direction (the attack angle), and, since the bays are open in different directions, the magnitude of wave set-up not only exhibits extensive variability along the coast but also reaches the largest values in different bayheads during different storms.

The objective of this paper is to evaluate the "climatology" of the set-up heights along this example of urban coast formed by a complicated geometry and hosting several vulnerable sections. First we reconstruct the statistics of wave conditions in the nearshore with a spatial resolution of about 0.25 nautical miles $(\sim 470 \mathrm{~m})$ for the years 1980 2012. This data set will then be used to identify the coastal sections prone to the highest set-up and, more importantly, to highlight the link between particular storms and stretches which have suffered from unexpectedly high water levels. The analysis reveals that the direction of storms has undergone some interesting decadal-scale variations. Perhaps the most unexpected feature is that almost each coastal section had its "own" (perfect) storm in the last three decades that produced the $30 \mathrm{yr}$ highest set-up in this section.

\section{Data and methods}

\subsection{Reconstruction of wave properties}

Although weather and wave observations covering Tallinn Harbour extend back to 1805 (Soomere, 2005), the older part of the data contains only visual estimates of wave properties. These data adequately represent wave fields in the proximity of the harbour but fail to describe the wave regime in other parts of the bay and, importantly, fail to identify the swelldominated conditions (which actually form about a half of all wave conditions); consequently these data also fail to find the predominant wave direction (Orlenko et al., 1984). Therefore, it is natural to use a contemporary wave-modelling system to reconstruct the time series of wave properties in the nearshore.

Wave properties were calculated using a triple-nested version of the third-generation spectral wave model called WAM (Komen et al., 1994). A coarse-resolution model was run for the whole Baltic Sea based on a regular grid with a discretisation of about 3 nautical miles $(5.5 \mathrm{~km}$ ) (see Fig. 1). At each sea point, 600 spectral components ( 24 evenly spaced directions and 25 frequencies ranging from 0.042 to $0.41 \mathrm{~Hz}$ with an increment of 1.1) were calculated. A medium-resolution model was run for the Gulf of Finland with a grid step of about $1.8 \mathrm{~km}$. The bathymetry of the model is based on data from Seifert et al. (2001) with a resolution of $1^{\prime}$ along latitudes and $2^{\prime}$ along longitudes. Additionally, a fine-resolution model with a grid step of about $470 \mathrm{~m}\left(1 / 4^{\prime}\right.$ along latitudes and $1 / 2^{\prime}$ along longitudes) resolving the major local topographic and bathymetric features was run for the Tallinn Bay area. The frequency range was extended to $2.08 \mathrm{~Hz}$ ( 42 evenly spaced frequencies) for wind speeds $\leq 10 \mathrm{~m} \mathrm{~s}^{-1}$ to better represent the wave growth in low-wind and short-fetch conditions. 
The WAM model, although constructed for open-ocean conditions and for relatively deep water (Komen et al., 1994), gives good results in the Baltic Sea basin provided the model resolution is appropriate and the wind information is correct. Extensive information about the model performance and validation for the Baltic can be found in Soomere et al. (2008a), Räämet et al. (2009), and Tuomi et al. (2011, 2012). Waves are relatively short in the Baltic Sea. Common wave periods are 3-6 s in the open Baltic proper (Broman et al., 2006) and usually even shorter $(2-4 \mathrm{~s})$ in its semi-enclosed sub-basins (Soomere and Räämet, 2011). They very occasionally reach $8-10 \mathrm{~s}$ in strong storms in the Baltic proper but almost never reach these levels in the Gulf of Finland or in Tallinn Bay (Soomere et al., 2008a, b). For a $1 \mathrm{~m}$-high wave with a rather long (in this context) period of $6 \mathrm{~s}$ the Ursell number in $5 \mathrm{~m}$ deep water is about 11 . Therefore, Stokes' theory is applicable up to about $3.5 \mathrm{~m}$ high waves with periods of $6 \mathrm{~s}$ in such conditions. As will be noted below, significant wave heights exceeding $3.5 \mathrm{~m}$ have not occurred in any of the areas prone to high set-up during the last three decades.

Moreover, the relatively shallow (less than $20 \mathrm{~m}$ deep) nearshore is fairly narrow, usually less than $1 \mathrm{~km}$ wide in most of the study area. The wave field thus experiences various non-linear shallow-water effects (such as the the frequency shift and spectral shape changes as water depth decreases or the impact of triad interactions) for a limited time and only during the propagation over a few 100s of metres. Therefore, it can be assumed that the chosen triple-nested implementation of the WAM wave model, run in the finite-depth mode, allows a satisfactory description of wave properties in the coastal zone, down to depths of about $5 \mathrm{~m}$ and as close to the coast as about $200-300 \mathrm{~m}$ in the study area. The output of this implementation has been compared with in situ measurements in Tallinn Bay in Soomere (2005).

Successful numerical wave modelling requires reliable marine wind information. The quality of wind data is a major issue in wave modelling in the Baltic Sea region, which has a large and complex-shaped water body that greatly influences surface-level winds and results in a high variability of the local climate in its vicinity. The existing global wind data sets have relatively low resolution and have to be downscaled for the use in the Baltic Sea conditions (Samuelsson et al., 2011; Schmager et al., 2008) but also artificially adjusted (e.g. using simulated gustiness) in order to properly replicate the air-sea interaction (Höglund et al., 2009). Local (national) wind data sets are only reliable in the vicinity of each country (Räämet et al., 2009), and high-resolution modelled winds, optionally coupled with wind sea properties, suffer from being substantially inhomogeneous over time (Tuomi et al., 2012). Furthermore, the Gulf of Finland has a specific wind and wave regime (Pettersson et al., 2010; Soomere et al., 2008b) mainly because the strongest winds blow obliquely across this water body with respect to the topography. The biggest problem in the reconstruction of wave set-up is the mismatch in the direction of even the best modelled versions of wind fields compared with high-quality measured data (Keevallik and Soomere, 2010).

A favourable feature is that the dimensions of the Gulf of Finland are smaller than the typical spatial extension of high and persistent wind events in the area. Thus the wind fields that produce the highest waves in this water body are approximately uniform over the entire gulf.

Based on the reasons listed, we consequently force the wave model with a spatially homogeneous wind field that matches the wind measured in fully marine conditions, at a location that is not affected by the presence of the mainland. Such a wind measurement site in the gulf is Kalbådagrund, a caisson lighthouse in the central part of the Gulf of Finland (Fig. 1, 59 $59^{\prime} \mathrm{N}, 25^{\circ} 36^{\prime} \mathrm{E}$ ). The wind measurements are performed at the height of $32 \mathrm{~m}$ above the mean sea level. Height correction factors, to reduce the recorded wind speed to the reference height of $10 \mathrm{~m}$, are 0.91 for neutral, 0.94 for unstable and 0.71 for stable stratifications (Launiainen and Laurila, 1984). To the first approximation, the factor 0.85 was used in the computations that follow.

The wave time series in the nearshore of the entire study area were estimated using a simplified scheme for longterm wave hindcasting. The basic idea of speeding up the wave computations consists of reducing long-term calculations of the sea state to an analysis of a cluster of wave field maps pre-computed with the use of single-point wind data. A favourable feature of the study area is that wave fields rapidly become saturated here and have relatively short memory (normally no longer than $12 \mathrm{~h}$ ) of wind history (Soomere, 2005). This feature makes it possible to split the wave calculations into a number of short independent sections of 3-12 h. To the first approximation, it was assumed that an instant wave field in Tallinn Bay is a function of a short section of the wind dynamics. Moreover, it was implicitly assumed that remote wind conditions in the open Baltic Sea did not significantly contribute to the local wave field in Tallinn Bay. A comparison of the results of modelling using the triple-nested wave model and the described method for reconstruction of wave fields (Soomere, 2005) suggests that the listed assumptions are valid in Tallinn Bay for about $99.5 \%$ of cases and thus the reconstructed wave properties are a good approximation to measured data.

The nearshore of the study area was divided into $105 \mathrm{sec}-$ tions with a typical length of $0.5 \mathrm{~km}$. For each section the average orientation of the coast and the limits of its variation were defined. The sections roughly correspond to the nearshore computational cells of the innermost, fineresolution wave model (Fig. 2).

The choice of cells used to evaluate the set-up height was based on estimates of the extreme wave heights in the Tallinn Bay area. For adequate estimates of the wave set-up, the cells should be as close to the coast as possible, but the modelled mean water depth in these cells should be bigger than the breaking depth for the largest waves. In many nearshore locations few storms produce significant wave heights of $\sim 4 \mathrm{~m}$. 


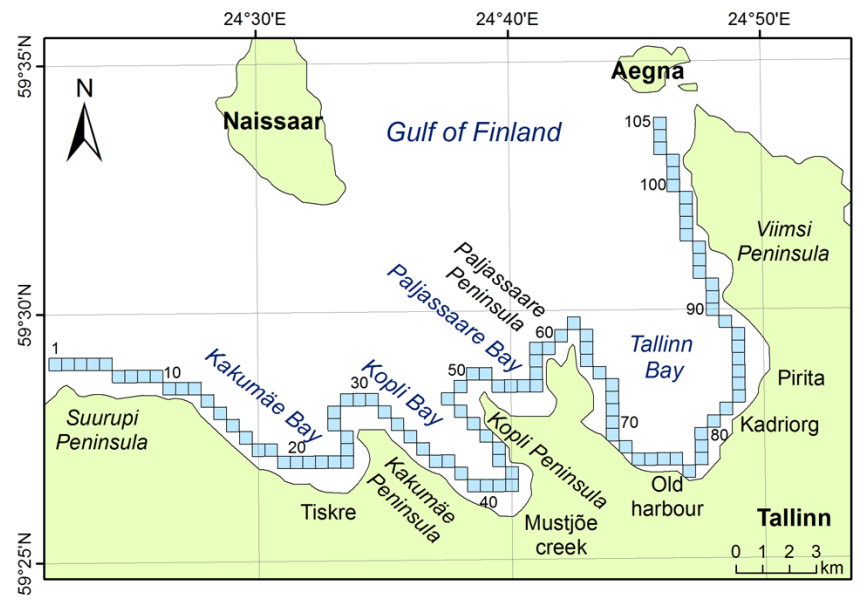

Fig. 2. Selected nearshore grid cells of the wave model. The cells are numbered sequentially starting from the westernmost point.

For example, on 15-16 November 2001, when the all-time high of the significant wave height of the Gulf of Finland $(5.2 \mathrm{~m})$ was recorded during a NNW storm (wind direction $330^{\circ}, 23 \mathrm{~m} \mathrm{~s}^{-1}$ ), the significant wave height in the interior of Tallinn Bay, and at the entrance to the two smaller bays, reached $4 \mathrm{~m}$ (Soomere, 2005). The significant wave height in an exceptional storm on 8-9 January 2005 was $4.5 \mathrm{~m}$ to the west of Naissaar (Soomere et al., 2008a). Therefore, waves in cells with a depth $<4 \mathrm{~m}$ may already be intensively breaking, and the use of wave data from these would severely underestimate the set-up height. Based on the listed reasons, the wave data were mostly used from nearshore cells that had a model water depth in the range of 4-8 $\mathrm{m}$. With this selection, the highest waves (producing also the highest set-up) were already close to the breaking stage in some computational cells. In a few cells that were associated with headlands, or points which are not vulnerable to high set-up, the water depth in the selected cells is, in some cases, up to 20$27 \mathrm{~m}$. A detailed analysis of further shoaling and refraction was performed to evaluate the breaking height and the approach angle at the seaward border of the surf zone based on the average orientation of the sections of the coast corresponding to the selected grid cells.

From the output of the WAM model, time series of the significant wave height, peak period and mean wave direction were evaluated once every $3 \mathrm{~h}$ from 1 January 1981 to 31 October 2012 for each selected coastal section. The set of wind data contained 93016 measurements. In 8554 cases either the wind speed or wind direction was missing. These incomplete data points were subsequently left out of the analysis, which was then based on the remaining 84462 measurements. The presence of ice was ignored. Doing so leads to a certain bias of the results, because the mean number of ice days varies from 70 to 80 annually (Climatological Ice Atlas, 1982; Sooäär and Jaagus, 2007). Statistically, the ice cover damps wind waves either partially or totally during the winter season, which is normally windier (Mietus, 1998). Therefore, the computed annual mean parameters of wind waves (as well as the corresponding extreme set-up) are somewhat overestimated and represent average wave properties during the years with no extensive ice cover.

\subsection{Evaluation of wave set-up}

As mentioned above, there is no consensus today about the exact relationship between the offshore wave properties and the parameters of wave set-up. The situation is actually even more complicated as the conversion of wave-driven momentum is very sensitive with respect to details of the nearshore (Dean and Bender, 2006), and the results of its modelling (e.g. using SWAN) show extensive dependence of the results on the model resolution and the slope of the beach (Nayak et al., 2012). The resolution used here gives a fair estimate (about $90 \%$ of the actual values) of wave set-up for gentle slopes (about $1: 80$ ), whereas it may fail to characterise this process for steeper slopes (about $1: 20$ ) (Nayak et al., 2012). The concave coastal stretches that host large values of maximum wave set-up are located in bayheads where the sediment is comparatively fine and the beach profiles have a relatively gentle slope in the surf zone (Soomere et al., 2007).

Given several uncertainties in the data set, limited knowledge about the nature of the particular nearshore areas, possible shortages in the evaluation of the wave parameters in single extreme storms and unresolved questions of the estimates of the set-up height, we specifically focus on the parameters of the climatology of wave set-up that are less sensitive with respect to the listed uncertainties but have a crucial role in the future management (including more detailed modelling) of the related issues. These are (i) the potential locations of the high set-up, (ii) a comparative climatology of set-up events and (iii) the properties and timing of typical storms that may produce high set-up in specific sections.

Solving the listed tasks, to a first approximation, is feasible using relatively simple parameterisations of the set-up height based on the primary wave properties. A straightforward estimate can be derived using the simplest concept of gradual wave breaking in the nearshore, namely that the ratio of the breaking-wave height $H_{\mathrm{b}}$ to the associated depth $d_{\mathrm{b}}-$ the so-called breaking index $\gamma_{\mathrm{b}}=H_{\mathrm{b}} / d_{\mathrm{b}}-$ remains constant in the entire surf zone (Lentz and Raubenheimer, 1999). In ideal conditions the maximum set-up height (Dean and Dalrymple, 1991) would be

$\bar{\eta}_{\max }=\frac{5}{16} \gamma_{\mathrm{b}} H_{\mathrm{b}}$.

The assumption of the constant value of $\gamma_{b}$ across the surf zone has been questioned by several authors (Raubenheimer et al., 1996; Power et al., 2010). On the one hand, there is some evidence that it probably increases shoreward (Raubenheimer et al., 2001; Yemm, 2004). But on the other hand, several observations in the surf zone have indicated that $\gamma_{\mathrm{b}}$ may 
be much smaller there (Lentz and Raubenheimer, 1999), and often only in the range of $0.2 \leq \gamma_{\mathrm{b}} \leq 0.5$ (Sallenger and Holman, 1985; Raubenheimer et al., 1996). This change may, to some extent, affect the numerical values of the wave set-up at specific, individual locations but evidently does not change the location of areas of high and low values of the set-up.

A commonly used assumption in coastal engineering is that a wave approaching a natural beach breaks when its height is $78 \%$ of the water depth at this location, so that equivalently the breaking index is $\gamma_{\mathrm{b}} \approx 0.78$ (Dean and Dalrymple, 1991, 2002). For strongly reflecting and/or steep beaches the breaking index may reach values $\sim 1.5$, while for domains with an almost horizontal bed it is in the range of 0.55-0.6 (Nelson, 1994; Massel, 1996). On sandy beaches $\bar{\eta}_{\max } \approx 0.17 H_{\mathrm{S} 10}$, where $H_{\mathrm{S} 10}$ is the significant wave height at a depth of $10 \mathrm{~m}$ (Guza and Thornton, 1981; Coastal Engineering Manual, 2002). These variations in the parameterisation of the maximum set-up evidently have a larger impact on the identification of the potential areas of high set-up. As the coasts in the study area considered here are mostly sedimentary with gently sloping profiles resembling Dean's equilibrium profile, the use of $\gamma_{\mathrm{b}}=0.8$ (Dean and Dalrymple, 1991) and, consequently, $\bar{\eta}_{\max } \approx 0.25 H_{\mathrm{b}}$ is justified for our purposes.

The time series of wave properties are calculated for a selection of grid cells located offshore the surf zone at different depths (Fig. 2). At many locations the water depth is much larger than the breaking depth for the waves generating the highest set-up; therefore it is necessary to account for the transformation of waves from the grid cells to the breaker line. The processes of shoaling and refraction during the wave propagation from the grid cells to the breaking line are evaluated using the common assumptions that (i) the numerically evaluated wave field is monochromatic, with (ii) the wave height equal to the modelled significant wave height, (iii) the period equal to the peak period, and (iv) wave directions matching the evaluated mean direction. This latter assumption implicitly means that the directional spreading of natural wave fields is ignored in the analysis; consequently, the onshore component of the radiation stress is overestimated by about 10-12\% (Feddersen, 2004). Moreover, we assume that within a particular coastal section the depth isolines seaward of the breaker line are straight and parallel to the average orientation of the coastline. This set of assumptions allows the use of linear wave theory for estimates of the breaking-wave height.

Let the wave height, group speed and celerity at a calculation point be $H_{0}, c_{\mathrm{g} 0}$ and $c_{\mathrm{f} 0}$, respectively. The height $H_{\mathrm{b}}$ at the breaking line is

$H_{\mathrm{b}}=H_{0}\left(\frac{c_{\mathrm{g} 0}}{c_{\mathrm{gb}}} \frac{\cos \theta_{0}}{\cos \theta_{\mathrm{b}}}\right)^{1 / 2}$,

where $\theta_{0}$ is the attack angle at the calculation point and $\theta_{\mathrm{b}}$ is the attack angle at the breaking line. Breaking waves are normally long waves and thus their group speed is $c_{\mathrm{gb}}=$ $\sqrt{g d_{\mathrm{b}}}=\sqrt{g H_{\mathrm{b}} / \gamma_{\mathrm{b}}}$, where $g$ is the acceleration due to gravity. The impact of refraction can be estimated from Snell's law $\sin \theta / c_{\mathrm{f}}=$ const along the wave rays. For the breaking waves the phase speed $c_{\mathrm{fb}}=c_{\mathrm{gb}}$ and thus

$\sin \theta_{\mathrm{b}}=\sin \theta_{0} \frac{c_{\mathrm{fb}}}{c_{\mathrm{f} 0}}=\sin \theta_{0} \frac{\sqrt{g H_{\mathrm{b}} / \gamma_{\mathrm{b}}}}{c_{\mathrm{f} 0}}$,

from which we reach the following equation with respect to the breaking height:

$$
\begin{aligned}
& H_{\mathrm{b}}^{4} c_{\mathrm{gb}}^{2}\left(1-\frac{c_{\mathrm{fb}}^{2}}{c_{\mathrm{f} 0}^{2}} \sin ^{2} \theta_{0}\right)= \\
& H_{\mathrm{b}}^{4} \frac{g H_{\mathrm{b}}}{\gamma_{\mathrm{b}}}\left(1-\frac{g H_{\mathrm{b}}}{\gamma_{\mathrm{b}}} \frac{\sin ^{2} \theta_{0}}{c_{\mathrm{f} 0}^{2}}\right)=H_{0}^{4} c_{\mathrm{g} 0}^{2}\left(1-\sin ^{2} \theta_{0}\right) .
\end{aligned}
$$

Equation (4) is an algebraic equation of 6th order with respect to $H_{\mathrm{b}}$ with three non-zero coefficients. The leading term and the constant term have the same sign, while the coefficient of $H_{\mathrm{b}}^{5}$ has the opposite sign. The relevant polynomial with respect to $H_{\mathrm{b}}$ has exactly one minimum at $\tilde{H}_{\mathrm{b}}=5 \gamma_{\mathrm{b}} c_{\mathrm{f} 0}^{2} /\left(6 g \sin ^{2} \theta_{0}\right)$ and tends to positive infinity if $H_{\mathrm{b}} \rightarrow \pm \infty$. Therefore, Eq. (4) has exactly two real positive solutions provided that

$6^{6} g^{4} H_{0}^{4} c_{\mathrm{g} 0}^{2} \sin ^{10} \theta_{0}\left(1-\sin ^{2} \theta_{0}\right) \leq 5^{5} \gamma_{\mathrm{b}}^{4} c_{\mathrm{f} 0}^{10}$.

It has a double, real solution if the expressions at the right- and left-hand side of Eq. (5) are equal, and has no real solutions for other combinations of the wave parameters and water depth. An estimate of the breaking-wave height is given by the smaller real solution. For almost-incident waves (for which the breaking angle $\theta_{\mathrm{b}}$ may be assumed zero and $\left.\cos \theta_{\mathrm{b}}=1\right)$ Eq. (4) can be reduced to an explicit formula for $H_{\mathrm{b}}$. The resulting expression under-predicts the breaking-wave height by approximately $12 \%$ (Dalrymple et al., 1977; Dean and Dalrymple, 1991). This under-prediction to some extent counterbalances the over-prediction of the onshore radiation stress stemming from the assumption of unidirectional waves.

Physical arguments suggest that Eq. (4) should always have real solutions if the modelled wave height is $H_{0}<$ $d_{\mathrm{b}} / \gamma_{\mathrm{b}}$, that is, the waves are not yet breaking. The domain of existence of real solutions to Eq. (4) is actually somewhat more limited by the inequality Eq. (5). This feature can be, to some extent, speculative as no rigorous proof seems to be easily available, attributed to the impact of the wave set-down in relatively shallow waters. This phenomenon to some extent decreases the effective water depth under large waves. The magnitude of this effect is (Longuet-Higgins and Stewart, 1964)

$\Delta d=-\frac{H_{0}^{2} k}{8 \sinh 2 k d}$, 


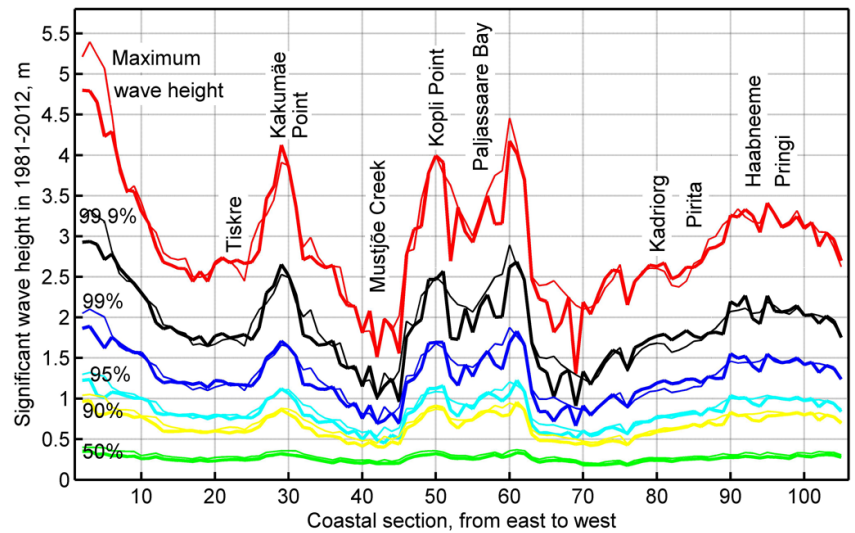

Fig. 3. Maximum wave heights, higher quantiles and median wave height in the nearshore of the study area in 1981-2012. Thin lines indicate the modelled wave heights, and bold lines show values for the breaking-wave heights calculated from Eq. (4). Geographical locations and the position of the coastal sections are indicated in Fig. 2.

where $k$ is the wave number and $d$ is the undisturbed water depth in the absence of waves. In our calculations, real valued solutions always exist if the modelled wave height was such that $H_{0}<(d+\Delta d) / \gamma_{\mathrm{b}}$.

The leading term of Eq. (4) vanishes for incident waves. In this case there is no refraction, and condition (2) reduces to $H_{\mathrm{b}}^{2}=H_{0}^{2} c_{\mathrm{g} 0} / c_{\mathrm{gb}}=H_{0}^{2} c_{\mathrm{g} 0} \sqrt{\gamma_{\mathrm{b}} /\left(g H_{\mathrm{b}}\right)}$, from which the breaking depth can be explicitly expressed as $H_{\mathrm{b}}=\left(H_{0}^{4} c_{\mathrm{g} 0}^{2} \gamma_{\mathrm{b}} / g\right)^{1 / 5}$ (Dean and Dalrymple, 1991). In calculations, the linear dispersion relation $\omega=2 \pi / T=$ $\sqrt{g k \tanh k d}$, where $\omega$ is the angular frequency and $T$ is the wave period, is solved exactly (that is, with about 7 correct decimal digits, which is the precision of replication of decimal numbers in a 32-bit computer) for wave number $k$ and water depth $d$ at the cell of the WAM model. These values were used to calculate the phase and group speed of the numerically modelled waves. In order to optimally replicate the behaviour of the largest waves, the peak period calculated by the WAM model was used as the wave period.

There were a few cases when the incoming wave height was very small (well below $10 \mathrm{~cm}$ ) and the ratio of the constant term to the coefficient of the leading term was also small, of the order of $10^{-7}$. In these cases the root-finding subroutine of the 32-bit computer failed to produce a solution, and an approximate value corresponding to the exact solution of Eq. (5) with a zero constant term was applied. These cases were, in any case, irrelevant for our purposes, as low wave heights do not lead to any real danger.

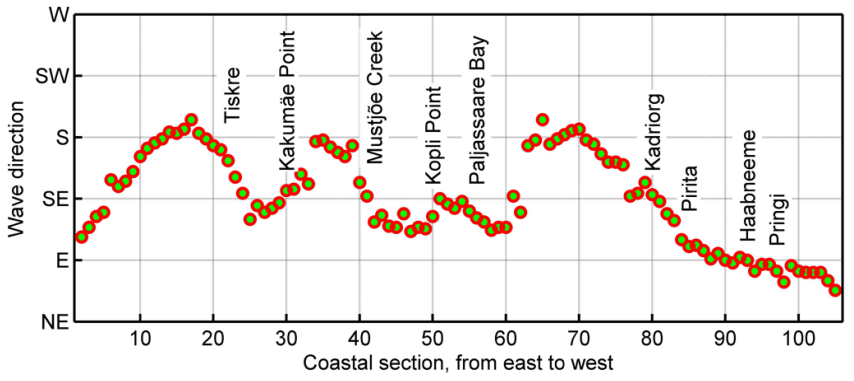

Fig. 4. Wave propagation directions corresponding to the highest waves that occurred in the study area in 1981-2012. Differing from meteorology, wave modellers indicate the direction in which waves propagate.

\section{Results}

\subsection{The highest waves}

The overall maximum wave height $H_{\max }$ in the study area was $5.4 \mathrm{~m}$ (Fig. 3). This value was reached only once at the westernmost section during a furious storm on 18-19 October 1998 when a westerly wind reached $25 \mathrm{~m} \mathrm{~s}^{-1}$ during two sequential measurement points in time, so over at least three hours. This coastal section (with a depth of $13 \mathrm{~m}$ in the model grid) is completely open to the west, north-west and north, that is, to the directions of the largest waves. The largest waves, not unexpectedly, occurred at the three headlands. The possibility of occurrence of quite high waves in the interior of Tallinn Bay (at Pirita Beach) and along the eastern coast of the Viimsi Peninsula reflects the predominance of western and NNW storms among those which produce large waves in the study area.

The wave propagation direction in the storms that have produced the highest waves in individual coastal sections varies considerably, from east to south-south-west. The results of Fig. 4 suggest that each section has its own perfect storm in which the largest waves occur. Such an extensive variation of the approach direction of the highest waves obviously reflects the complexity of the geometry of the study area and simply mirrors the fact that different coastal sections are open to waves from different directions.

All the highest-ever waves in the study occurred in four storms (Fig. 5): western storm on 18-19 October 1998 (maximum wind speed $25 \mathrm{~m} \mathrm{~s}^{-1}$, direction $260^{\circ}-280^{\circ}$ ), WSW to WNW storm on 29 November $1999\left(25 \mathrm{~m} \mathrm{~s}^{-1}, 220^{\circ}-290^{\circ}\right)$, NNW storm on 15-16 November $2001\left(23 \mathrm{~m} \mathrm{~s}^{-1}, 320^{\circ}\right.$ $\left.340^{\circ}\right)$, and NW storm of $27-28$ October $2006\left(23 \mathrm{~m} \mathrm{~s}^{-1}\right.$, $300^{\circ}-320^{\circ}$ ). Among these, the storm of 15-16 November 2001 set the previous maximum water level $(1.35 \mathrm{~m})$ in Tallinn Bay (Suursaar et al., 2006). The peak periods (not shown) were all in the range of $7-9 \mathrm{~s}$ in these events. Three of the listed storms created the highest waves in most of the study area, whereas the storm of 29 November 1999 produced the highest waves only in three coastal sections. 


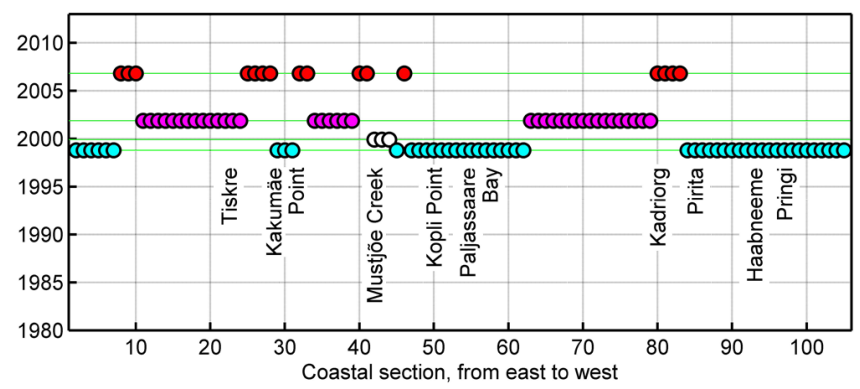

Fig. 5. Four storms (marked with different colours) that caused the highest waves in the study area in 1981-2012.

Interestingly, the "one-hundred-year storm" on 8-9 January 2005 that produced the all-time peak water level for many sites in the eastern Baltic Sea (Suursaar et al., 2006), and also very high waves in the Gulf of Finland (Soomere et al., 2008a), did not produce very high waves in any section of the study area. Another interesting feature of Fig. 5 is that all of the highest waves have occurred during the last decade. This may be indicative of an increase in the overall wind speed. However, another explanation - that the predominant wind direction in the strongest storms has changed over the decades - seems to be a more adequate explanation as will be discussed below.

The ratio of the maximum wave height and the 99.9 percentile (not shown) varies by about $30 \%$ in the study area, from 1.42 to 1.78 . This level of variation signals that in this region the distributions of different wave heights may have quite different properties for different sections. Although not unexpected, this feature also indicates that the straightforward use of the classical estimates for properties in the nearshore (such as the closure depth or the width of the equilibrium beach profile), developed for open-ocean coasts, may lead to considerable errors for Baltic Sea conditions. For example, the simplified estimate (Houston, 1996) for the closure depth based on the annual average significant wave height implicitly assumes that the ratio of the 99.863 percentile $\left(H_{0.137} \%\right.$ or threshold for the wave height that is exceeded $12 \mathrm{~h}$ a year) and the annual average wave height $H_{\text {mean }}$ is 4.5 . This ratio varies from about 3.7 to 6.1 , whereas its average over the study area is about 5 .

\subsection{Almost-incident waves}

The analysis performed here was for waves approaching from any direction. The approach angle of such waves varies from almost zero up to $90^{\circ}$ for several sections located at headlands and even up to $135^{\circ}$ for one section (Fig. 6). Waves that approach the coast obliquely mostly produce longshore current rather than high set-up because the cross-shore component of the radiation stress is mostly responsible for set-up (Apotsos et al., 2008). The highest set-up occurs when waves approach the coast almost perpendicularly (i.e. normal to the

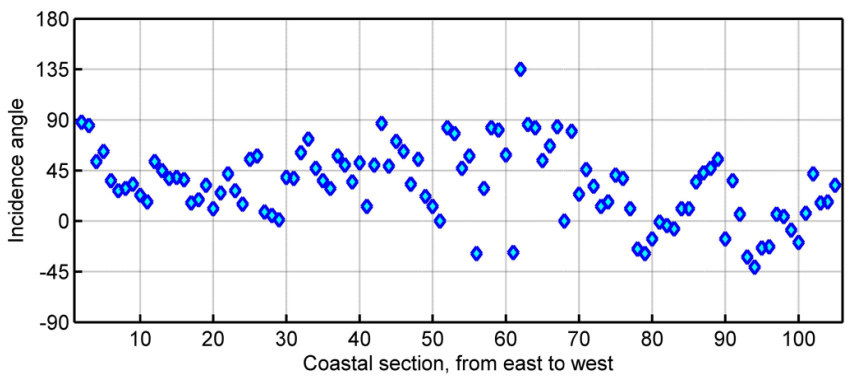

Fig. 6. The angle between the normal to the coast and wave approach direction for the highest waves in the study area in 19812012.

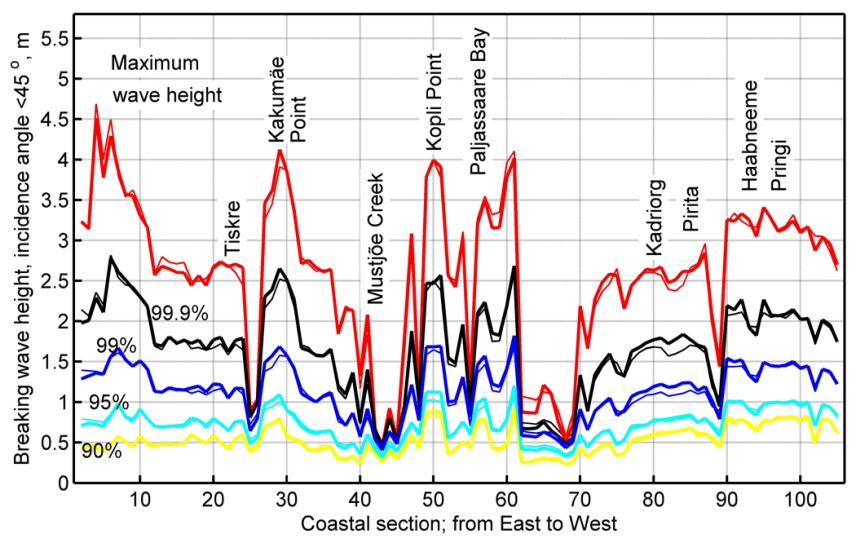

Fig. 7. Maximum wave heights, higher quantiles and median wave height for waves approaching from the direction of maximally $\pm 45^{\circ}$ with respect to the normal to the coast. Thin lines indicate the modelled wave heights, and bold lines show values for the breakingwave heights calculated from Eq. (4).

coastline). The crucial parameter for extreme set-up height is the maximum height of waves that approach a coastal section from a narrow range of direction. If the height of such almost-incident waves is much lower than the all-term highest waves, the onshore component of the radiation stress in such waves is relatively limited and the problem with high set-up may not occur at all.

Not surprisingly, both extreme and average wave heights from a narrow direction range, with respect to the normal to the coast (Fig. 7), are much lower than those pictured in Fig. 3. The largest decrease occurs in semi-sheltered sections of the coast, whereas such wave heights for a few headlands remain almost unchanged. Several such sections are implicitly protected by the geometrical shape of the bays (Caliskan and Valle-Levinson, 2008), or by intense refraction of wave fields that redirects part of the wave energy towards the coastal stretches that are located relatively close to the entrance of the bay and, in this way, reduces the wave height in the bay interior. 


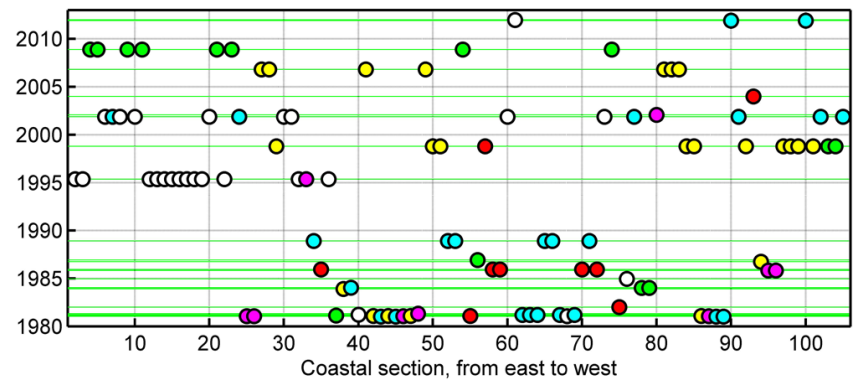

Fig. 8. Pattern of storms generating the highest waves approaching from the direction of $\pm 15^{\circ}$ with respect to the normal to the coast. The horizontal lines indicate storms that produced the highest almost-normal waves at least in one coastal section. Each storm is marked with a single colour. The colours vary cyclically.

Given the highly variable orientation of the coastline, it is natural to expect that for certain coastal sections the highest waves that approach the coast directly are generated by storms that are not among the strongest ones. Somewhat surprisingly, the collection of storms that produce the highest waves changes radically if waves whose propagation direction is at a relatively small angle to the coast normal are considered. While only four storms were responsible for the alltime highest waves in the study area, 18 different storms produce the all-time highest waves approaching the coast at an angle less than $\pm 45^{\circ}$ with respect to the normal to the coast. The number of different storms increases to 32 if only waves approaching the coast at an angle less than $\pm 30^{\circ}$ are considered and increases to 41 for almost-incident waves $\left( \pm 10^{\circ}\right)$. Apart from the increase in the number of such storms, their distribution over the time period in question changes radically. For example, for the highest waves approaching from the direction of $\pm 15^{\circ}$ (Fig. 8), the four storms depicted in Fig. 5 are only responsible for the all-time highest set-up in about $1 / 3$ of the coastal sections. The above-mentioned storm in January 2005 does not feature in this measure at all.

A large number of all-time highest almost-incident waves (and thus of the all-time highest wave set-up in the relevant section) occurred in the 1980s. As many coastal sections around Tallinn (which was much smaller then) were not open to the public, these events evidently remained unnoticed and therefore are not accounted for in contemporary statistics (which started after Estonia obtained independence in the beginning of the 1990s). A particularly deceptive feature of the short-term statistics for decision-makers is the period of relatively low wave activity in the 1990s from the directions to which the coasts of the city of Tallinn are open. It is thus not surprising that the statistics of storms and high wave-induced set-up can be misleadingly interpreted as showing a rapid increase in a certain type of wave activity at the turn of the millennium. A much more appropriate explanation is that the directional structure of strong storms exhibits decadal-scale variations in the region of the Gulf of Finland.

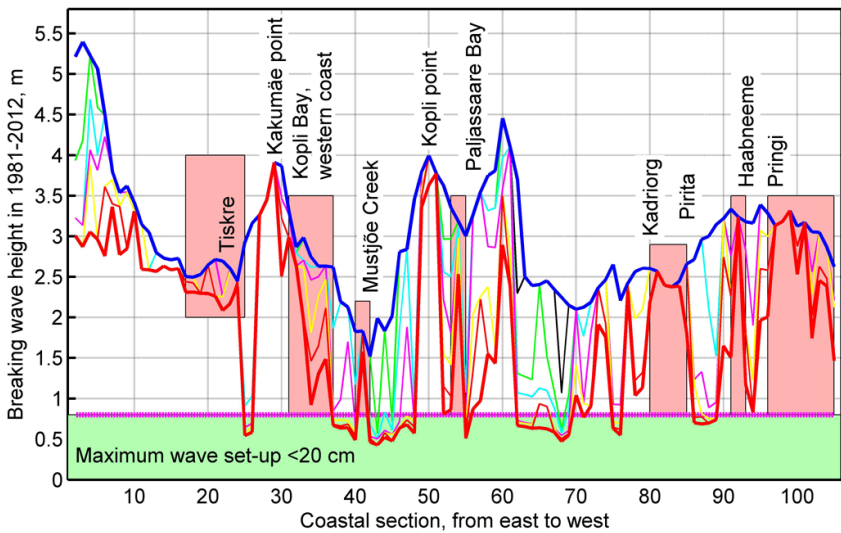

Fig. 9. Highest breaking waves (coloured lines) approaching from different ranges of directions with respect to the coast normal in the study area. The bold blue line shows the all-time highest waves approaching from any direction, and the bold red line shows the alltime highest almost-incident waves $\left( \pm 10^{\circ}\right.$ with respect to the coast normal). The light red bars indicate the regions with gently sloping coast in which the maximum set-up likely exceeds $40 \mathrm{~cm}$.

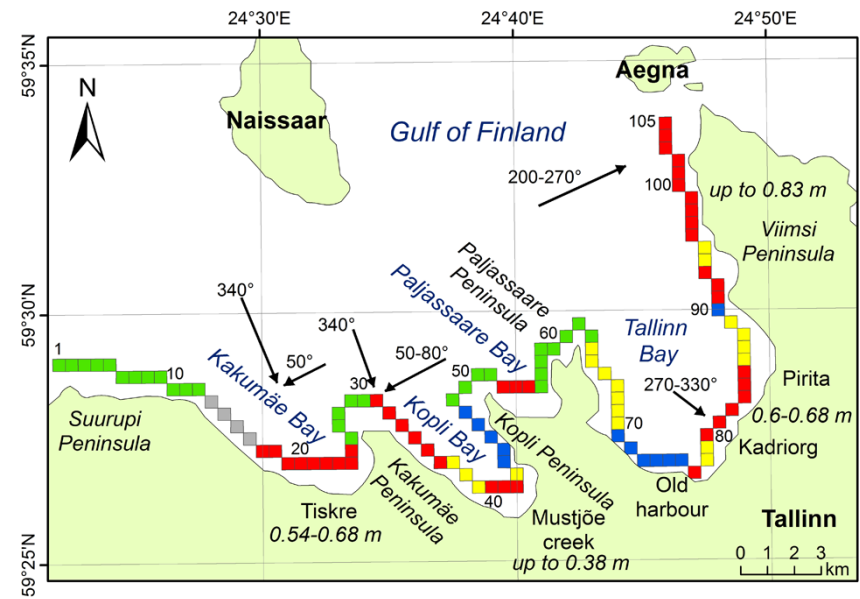

Fig. 10. Areas around Tallinn potentially affected by high wave set-up (red squares indicate the maximum set-up) with the respective directions of wave propagation (arrows). Yellow squares indicate coastal stretches where the maximum wave set-up is less than $20 \mathrm{~cm}$, green squares indicate areas where high set-up is evidently not possible because of the convex shape of the coastline, grey squares indicate areas naturally protected by a cliff and blue squares represent areas containing various engineering structures.

\subsection{The endangered areas}

The areas endangered by high wave set-up are coastal sections with a convex shape that are often affected by high almost-incident waves. Areas satisfying the latter condition can be easily identified by gradually narrowing the range of directions of high waves (Fig. 9). A decision about whether dangerous values of wave set-up may actually occur also requires the geographical map of the area (Fig. 10) and data 


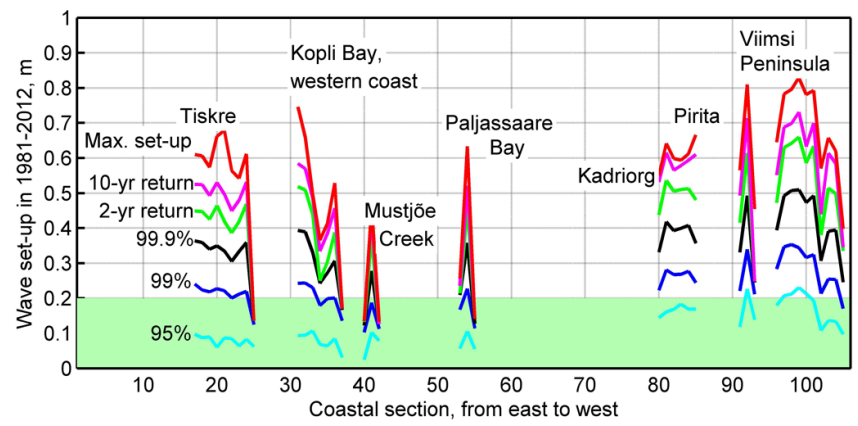

Fig. 11. Maximum wave set-up values, higher quantiles of set-up heights and $2 \mathrm{yr}$ and $10 \mathrm{yr}$ return values of set-up heights for the coastal sections where high set-up is an issue.

about the nature of particular sections of the coastline. It turns out that substantial levels of wave set-up are likely in the residential area of Tiskre and specifically along the western coast of the Viimsi Peninsula. The danger is relatively low at the mouth of Mustjõe Creek - an area that technically is open to high waves but which apparently is implicitly protected by a favourable combination of the geometry and bathymetry of Kopli Bay.

It is not clear whether or not the danger of high wave set-up actually occurs along the north-eastern coast of the Kakumäe Peninsula. The related hazards are apparently minor along the coastal section from Old City Harbour to Pirita, where the coastline is protected by a seawall that reflects the wave energy and prevents set-up.

The above results have been presented and discussed in terms of maximum wave set-up heights occurring once in a $30 \mathrm{yr}$ period. A somewhat better indication of the realistic level of danger for the coastal stretches that may be affected by high wave set-up provides an estimate of the highest quantiles for the set-up (Fig. 11). While it is expected that the alltime highest values of set-up are an isolated phenomenon, in several areas the 99.9 percentile of the set-up height is quite high, close to $40 \mathrm{~cm}$. For the particular conditions of Tallinn Bay it means that an addition of the magnitude of $25 \%$ of the all-time highest open sea water level occurs in these locations, on average, three times a year. Although these events are not necessarily associated with the overall high water level, such a high occurrence suggests that simultaneous attack of high open sea water level and wave set-up is very likely in these locations. This conjecture is supported by relatively large $2 \mathrm{yr}$ and $10 \mathrm{yr}$ return values of the set-up height in some locations (Fig. 11).

\section{Conclusions and discussion}

The analysis presented here confirms the well-known conjecture that wave set-up serves as an important constituent of marine-induced coastal hazard. Although several assumptions made in the analysis may, to some extent, oversimplify the situation and the individual estimates may have quite large uncertainty, the key conclusion is that the contribution of wave set-up may be up to $50 \%$ of the maximum water levels caused by other factors in areas that are open to predominant wind and wave directions. In other words, wave set-up may frequently form about $1 / 3$ of the total water level increase during specific storms. This results in a considerable increase in the risk of coastal flooding in regions that normally experience a relatively small range of the fluctuations of the local water level such as the Baltic Sea, Black Sea or the Mediterranean Sea.

The extensive variation given here of the climatological properties of set-up heights along the study area highlights a particularly insidious feature of this phenomenon - its substantial dependence on the match of the wave propagation direction and the geometry of the coastline. This feature is probably not decisive along open-ocean coasts, where high waves usually approach the coast under small incidence angles and produce high set-up in long coastal stretches. It is, however, accentuated in semi-sheltered domains with complex geometry of the coastline where the location of high setup may substantially vary, depending not only on the storm wind direction but also on the wave period (which affects the intensity of refraction and thus also the wave approach direction). The resulting, dangerously high, set-up in selected coastal sections may be easily overlooked or, especially in urban areas, associated with other phenomena (e.g. heavy rainfall, snow melt or flash flooding of a river).

The analysis of the climatology of high set-up events in such areas with complex geometry is thus additionally complicated because the return period of unfavourable combinations of wind and wave properties is substantially larger than that of just high waves or water levels alone. On the one hand, this peculiarity requires us to obtain much longer time series of wave set-up in order to reach adequate statistics of this phenomenon in coastal sections that are orientated differently, similarly to the proper evaluation of statistics of winds from particular directions. On the other hand, this phenomenon, if it occurs, contains particularly large hazards in low-lying urban environments, with possibly significant implications on the functioning of infrastructure in neighbouring areas and on the availability of evacuation roads.

There are several simple ways to avoid high wave set-up. For example, this phenomenon normally does not occur if the coast is protected by a seawall. Another, option is to use "soft" measures, e.g. the ability of natural roughness of the coastal zone (reed, bushes and stones) to substantially damp out this phenomenon. As high set-up is dangerous in combination with high water levels, this means that it is sensible to keep naturally occurring bushes at the level of the maximum expected storm surge, an option that is not always easy to explain to the decision-makers, the public and especially to developers. This is thus is a challenge for smart and sustainable planning and management of urban coastal areas, but it 
is a natural, low-cost measure to mitigate this type of marine coastal hazard.

The numerical values of the set-up climatology presented here have been evaluated in ideal conditions additionally using a number of approximations, and thus they should be interpreted as indicative values. The correspondence between the results and estimates derived from in situ observations suggests that the estimates are still realistic in cases when the set-up process is not unduly affected by wave reflection or damping. The danger here is that the estimates are invariant with respect to the background water level. In other words, even if the nearshore is stony, as it is in many locations of the coastline of Tallinn especially along the Viimsi Peninsula, then in the case of a considerable storm surge (say, about $1 \mathrm{~m})$ the waves will break in a completely different location. Therefore, developed areas (e.g. lawned gardens, parking areas) theoretically within reach of high water may become sources of increased risk, in terms of extensive wave set-up. The analysis above shows that potentially affected areas form in total about $50 \%$ of the entire coastline. This estimate, although very rough, simply expresses the balance between the convex- and concave-shaped sections of the coastline.

The intermittent character of the location of coastal stretches which experience high set-up, and the strong dependence of the areas with highest set-up on the properties of a particular storm, is a major challenge for any crisis management team. Although the parameters of approaching waves can be predicted with quite good quality nowadays, the prediction of high set-up requires a proper replication of wave periods (which is a challenge anyway even for the very best contemporary wave models) and wave propagation directions. In essence, this problem is equivalent to the exact forecast of a hurricane landing point, where there is still some room for improvement.

Apart from the analysis of the properties of hazard for this intricate coastline, the results included here give an interesting insight into some potentially deceptive features of wave statistics. If one concentrates on the properties of the highest waves, Fig. 5 produces an impression that the 1980s and 1990s were relatively mild and that the wave climate has become considerably more severe since the end of the 1990s. Figure 8 clarifies the picture by demonstrating that, for many directions, the strongest wave storms occurred at the beginning of the 1980s. Moreover, it suggests that the wave climate (in terms of the number of coastal sections in a particular year where the all-time highest wave set-up has been reached) has become clearly milder now than it was in the 1980s. In essence, this controversy basically reflects the core property of climate changes in the northern Baltic Sea and probably in many other areas in the world: changes become more evident in the wind direction rather than in the wind strength. This aspect of climate change is perhaps underrated today, although the related changes in the wave propagation direction eventually have major consequences on the coastal processes (Charles et al., 2012a, b; Räämet et al., 2010). A more detailed analysis of various wave phenomena may thus give some extremely interesting insight into this still unidentified feature of climate change.

Acknowledgements. This study was a part of the project "Sciencebased forecast and quantification of risks to properly and timely react to hazards impacting Estonian mainland, air space, water bodies and coasts" (TERIKVANT) supported by the European Union (European Regional Development Fund, ERDF) and managed by the Estonian Research Council in the framework of the environmental technology R\&D programme KESTA. The research was partially supported by the targeted financing of the Estonian Ministry of Education and Research (grant SF0140007s11), by the Estonian Science Foundation (grant no. 9125), and through support of the ERDF to the Centre of Excellence in Non-linear Studies (CENS) and the Mobilitas project MTT63. The authors are deeply grateful to the Finnish Meteorological Institute for providing Kalbådagrund wind data. Financial contribution of the city of Tallinn towards detailed analysis of wave properties in particularly endangered coastal stretches is gratefully acknowledged.

Edited by: I. Didenkulova

Reviewed by: two anonymous referees

\section{References}

Apotsos, A., Raubenheimer, B., Elgar, S., Guza, R. T., and Smith, J. A.: Effect of wave rollers and bottom stress on wave setup, J. Geophys. Res.-Oceans 112, C02003, doi:10.1029/2006JC003549, 2007.

Apotsos, A., Raubenheimer, B., Elgar, S., and Guza, R. T.: Wave-driven setup and alongshore flows observed onshore of a submarine canyon, J. Geophys. Res.-Oceans, 113, C07025, doi:10.1029/2007JC004514, 2008.

Bertin, X., Fortunato, A. B., and Oliveira, A.: A modeling-based analysis of processes driving wave-dominated inlets, Cont. Shelf Res., 29, 819-834, 2009.

Broman, B., Hammarklint, T., Rannat, K., Soomere, T., and Valdmann, A.: Trends and extremes of wave fields in the north-eastern part of the Baltic Proper, Oceanologia, 48, 165-184, 2006.

Caliskan, H. and Valle-Levinson, A.: Wind-wave transformations in an elongated bay, Cont. Shelf Res., 28, 1702-1710, 2008.

Cariolet, J.-M. and Suanez, S.: Method of mapping flood hazard in low-lying coasts, Houille Blanche, 2, 52-58, 2009.

Charles, E., Idier, D., Thiebot, J., Le Cozannet, G., Pedreros, R., Ardhuin, F., and Planton, S.: Present wave climate in the Bay of Biscay: Spatiotemporal variability and trends from 1958 to 2001, J. Climate, 25, 2020-2039, 2012a.

Charles, E., Idier, D., Delecluse, P., Deque, M., and Le Cozannet, G.: Climate change impact on waves in the Bay of Biscay, France, Ocean Dynam., 62, 831-848, 2012b.

Cheng, X. T., Evans, E. P., Wu, H. Y., Thorne, C. R., Han, S., Simm, J. D., and Hall, J. W.: A framework for long-term scenario analysis in the Taihu Basin, China, J. Flood Risk Manage., 6, 3-13, 2013.

Climatological Ice Atlas for the Baltic Sea, Kattegat, Skagerrak and Lake Vänern (1963-1979), Swedish Meteorological and Hydro- 
logical Institute, Norrköping, Sweden, and Institute of Marine Research, Helsinki, Finland, Norrköping, 1982.

Coastal Engineering Manual: U. S. Army Corps of Engineers (USACE), Manual EM 1110-2-1100, 2002.

Dalrymple, R. A., Eubanks, R. A., and Birkemeier, W. A.: Waveinduced circulation in shallow basins, J. Waterw. Ports Coast. Ocean Div. ASCE, 103, 117-135, 1977.

Dawson, R. J., Speight, L., Hall, J. W., Djordjevic, S., Savic, D., and Leandro, J.: Attribution of flood risk in urban areas, J. Hydroinform., 10, 275-288, 2008.

Dean, R. G. and Bender, C. J.: Static wave set-up with emphasis on damping effects by vegetation and bottom friction, Coast. Eng., 53, 149-165, 2006.

Dean, R. G. and Dalrymple, R. A.: Water wave mechanics for engineers and scientists, World Scientific, 1991.

Dean, R. G. and Dalrymple, R. A.: Coastal Processes with Engineering Applications, Cambridge University Press, Cambridge, 2002.

Feddersen, F.: Effect of wave directional spread on the radiation stress: comparing theory and observations, Coast. Eng., 51, 473481, 2004.

Filipot, J.-F. and Cheung, K. F.: Spectral wave modeling in fringing reef environments, Coast. Eng., 67, 67-79, 2012.

Guza, R. T. and Thornton, E. B.: Wave set-up on a natural beach, J. Geophys. Res.-Ocean Atmos., 86, 4133-4137, 1981.

Hall, J. W., Dawson, R. J., Barr, S. L., Batty, M., Bristow, A. L., Carney, S., Dagoumas, A., Ford, A. C., Harpham, C., Tight, M. R., Walsh, C. L., Watters, H., and Zanni, A. M.: City-scale integrated assessment of climate impacts, adaptation, and mitigation, in: Energy efficient cities: assessment tools and benchmarking practices, edited by: Bose, R. K., The World Bank, 63-83, 2010.

Harper, B., Hardy, T., Mason, L., and Fryar, R.: Developments in storm tide modelling and risk assessment in the Australian region, Nat. Hazards, 51, 225-238, 2009.

Heidarzadeh, M., Bonneton, P., Bonneton, N., and Tissier, M.: Field observations of wave-induced set-up on the french Aquitanian coast, in: Proceedings of the 28th International Conference on Ocean, Offshore and Arctic Engineering (OMAE 2009), Honolulu, 31 May-5 June 2009, ASME, vol. 4, 233-241, 2009.

Höglund, A., Meier, H. E. M., Broman, B., and Kriezi, E.: Validation and correction of regionalised ERA-40 wind fields over the Baltic Sea using the Rossby Centre Atmosphere Model RCA3.0, Rapport Oceanografi No. 97, Swedish Meteorological and Hydrological Institute, Norrköping, Sweden, 2009.

Houston, J. R.: Simplified Dean's method for beach-fill design, J. Waterw. Port C-ASCE 122, 143-146, 1996.

Hsu, T.-W., Hsu, J. R.-C., Weng, W.-K., Wang, S.-K., and Ou, S.-H.: Wave setup and setdown generated by obliquely incident waves, Coast. Eng., 53, 865-877, 2006.

Irish, J. L. and Canizares, R.: Storm-wave flow through tidal inlets and its influence on bay flooding, J. Waterw. Port C-ASCE, 135, 52-60, 2009.

Jain, I., Rao, A. D., Jitendra, V., and Dube, S. K.: Computation of expected total water levels along the east coast of India, J. Coastal Res., 26, 681-687, 2010a.

Jain, I., Rao, A. D., and Ramesh, K. J.: Vulnerability assessment at village level due to tides, surges and wave set-up, Mar. Geod., 33, 245-260, 2010b.
Keevallik, S. and Soomere, T.: Towards quantifying variations in wind parameters across the Gulf of Finland, Estonian J. Earth Sci., 59, 288-297, 2010.

Komen, G. J., Cavaleri, L., Donelan, M., Hasselmann, K., Hasselmann, S., and Janssen, P. A. E. M.: Dynamics and modelling of ocean waves, Cambridge University Press, Cambridge, 1994.

Launiainen, J. and Laurila, T.: Marine wind characteristics in the northern Baltic Sea, Finnish Mar. Res., 250, 52-86, 1984.

Lentz, S. and Raubenheimer, B.: Field observations of wave setup, J. Geophys. Res.-Oceans, 104, 867-875, 1999.

Longuet-Higgins, M. S. and Stewart, R. W.: Radiation stresses in water waves: a physical discussion with applications, Deep-Sea Res., 11, 529-562, 1964.

Massel, S. R.: On the largest wave height in water of constant depth, Ocean Eng., 23, 553-573, 1966.

McInnes, K. L., O’Grady, J. G., and Hubbert, G. D.: Modelling sea level extremes from storm surges and wave set-up for climate change assessments in southeastern Australia, J. Coastal Res., Special Issue, 56, 1005-1009, 2009.

Mietus, M. (Ed.): The climate of the Baltic Sea Basin. Marine meteorology and related oceanographic activities, Rep. No. 41, World Meteorol. Org. Geneva, 64 pp., 1998.

Nayak, S., Bhaskaran, P., and Venkatesan, R.: Near-shore wave induced set-up along Kalpakkam coast during an extreme cyclone event in the Bay of Bengal, Ocean Eng., 55, 52-61, 2012.

Nelson, R. C.: Depth limited design wave heights in very flat regions, Coastal Eng., 23, 43-59, 1994.

O'Grady, J. G. and McInnes, K. L.: Wind waves and their relationship to storm surges in northeastern Bass Strait, Aust. Meteorol. Oceanogr. J., 60, 265-275, 2010.

Orlenko, L. R., Lopatukhin, L. I., and Portnova, G. L. (Eds.): Studies of hydrometeorological regime of Tallinn Bay, Gidrometeoizdat, Leningrad, 1984 (in Russian).

Pettersson, H., Kahma, K. K., and Tuomi, L.: Wave directions in a narrow bay, J. Phys. Oceanogr., 40, 155-169, 2010.

Power, H. E., Hughes, M. G., Aagaard, T., and Baldock, T. E.: Nearshore wave height variation in unsaturated surf, J. Geophys. Res.-Oceans, 115, C08030, doi:10.1029/2009JC005758, 2010.

Räämet, A., Suursaar, Ü., Kullas, T., and Soomere, T.: Reconsidering uncertainties of wave conditions in the coastal areas of the northern Baltic Sea, J. Coastal Res., Special Issue, 56, 257-261, 2009.

Räämet, A., Soomere, T., and Zaitseva-Pärnaste, I.: Variations in extreme wave heights and wave directions in the north-eastern Baltic Sea, Proc. Estonian Acad. Sci., 59, 182-192, 2010.

Raubenheimer, B., Guza, R. T., and Elgar, S.: Wave transformation across the inner surf zone, J. Geophys. Res.-Oceans, 101, 2558925597, 1996.

Raubenheimer, B., Guza, R. T., and Elgar, S.: Field observations of set-down and set-up, J. Geophys. Res.-Oceans, 106, 4629-4638, 2001.

Raukas, A. and Hyvärinen, H. (Eds.): Geology of the Gulf of Finland, Valgus, Tallinn, 1992 (in Russian).

Sallenger, A. H. and Holman, R. A.: Wave energy saturation on a natural beach of variable slope, J. Geophys. Res.-Oceans, 90, 11939-11944, 1985.

Samuelsson, P., Jones, C. G., Willén, U., Ullerstig, A., Gollvik, S., Hansson, U., Jansson, C., Kjellström, E., Nikulin, G., and 
Wyser, K.: The Rossby Centre Regional Climate Model RCA3: Model description and performance, Tellus A, 63, 4-23, 2011.

Schmager, G., Fröhle, P., Schrader, D., Weisse, R., and MüllerNavarra, S.: Sea state, tides, in: State and evolution of the Baltic Sea 1952-2005, edited by: Feistel, R., Nausch, G., and Wasmund, N., Wiley, Hoboken, New Jersey, 143-198, 2008.

Seifert, T., Tauber, F., and Kayser, B.: A high resolution spherical grid topography of the Baltic Sea, 2nd Edn., Baltic Sea Science Congress, Stockholm 25-29 November 2001, Poster \#147, available at: www.io-warnemuende.de/iowtopo, 2001,

Shi, F. and Kirby, J. T.: Discussion of "Wave set-up and setdown generated by obliquely incident waves" by T.-W. Hsu et al., Coastal Engineering, 53, 865-877, 2006, Coast. Eng., 55, 12471249,2008

Sooäär, J. and Jaagus, J.: Long-term variability and changes in the sea ice regime in the Baltic Sea near the Estonian coast, Proc. Estonian Acad. Sci. Eng., 13, 189-200, 2007.

Soomere, T.: Wind wave statistics in Tallinn Bay, Boreal Environ. Res., 10, 103-118, 2005.

Soomere, T.: Wave regimes and anomalies off north-western Saaremaa Island, Proc. Estonian Acad. Sci. Eng., 7, 157-173, 2001.

Soomere, T. and Räämet, A.: Spatial patterns of the wave climate in the Baltic Proper and the Gulf of Finland, Oceanologia, 53, 335-371, 2011

Soomere, T., Kask, A., Kask, J., and Nerman, R.: Transport and distribution of bottom sediments at Pirita Beach, Estonian J. Earth Sci. 56, 233-254, 2007.

Soomere, T., Behrens, A., Tuomi, L., and Nielsen, J. W.: Wave conditions in the Baltic Proper and in the Gulf of Finland during windstorm Gudrun, Nat. Hazards Earth Syst. Sci., 8, 37-46, doi:10.5194/nhess-8-37-2008, 2008a.

Soomere, T., Myrberg, K., Leppäranta, M., and Nekrasov, A.: The progress in knowledge of physical oceanography of the Gulf of Finland: a review for 1997-2007, Oceanologia, 50, 287-362, $2008 b$.
Starr, V. P.: A momentum integral for surface waves in deep water, J. Mar. Res., 6, 126-135, 1947.

Stockdon, H. F., Holman, R. A., Howd, P. A., and Sallenger, A. H.: Empirical parameterization of set-up, swash, and runup, Coast. Eng., 53, 573-588, 2006.

Suursaar, Ü., Kullas, K., Otsmann, M., Saaremäe, I., Kuik, J., and Merilain, M.: Hurricane Gudrun and modelling its hydrodynamic consequences in the Estonian coastal waters, Boreal Environ. Res., 11, 143-159, 2006.

Torresan, S., Critto, A., Rizzi, J., and Marcomini, A.: Assessment of coastal vulnerability to climate change hazards at the regional scale: the case study of the North Adriatic Sea, Nat. Hazards Earth Syst. Sci., 12, 2347-2368, doi:10.5194/nhess-12-23472012, 2012.

Torres-Freyermuth, A., Maríno-Tapia, I., Coronado, C., Salles, P., Medellín, G., Pedrozo-Acuña, A., Silva, R., Candela, J., and Iglesias-Prieto, R.: Wave-induced extreme water levels in the Puerto Morelos fringing reef lagoon, Nat. Hazards Earth Syst. Sci., 12, 3765-3773, doi:10.5194/nhess-12-3765-2012, 2012.

Trenhaile, A. S.: Modeling the erosion of cohesive clay coasts, Coast. Eng., 56, 59-72, 2009.

Tuomi, L., Kahma, K. K., and Pettersson, H.: Wave hindcast statistics in the seasonally ice-covered Baltic Sea, Boreal Environ Res., 16, 451-472, 2011.

Tuomi, L., Kahma, K. K., and Fortelius, C.: Modelling fetch-limited wave growth from an irregular shoreline, J. Marine Syst., 105, 96-105, 2012.

Valdmann, A., Käärd, A., Kelpšaitè, L., Kurennoy, D., and Soomere, T.: Marine coastal hazards for the eastern coasts of the Baltic Sea, Baltica, 21, 3-12, 2008.

Vetter, O., Becker, J.-M., Merrifield, M. A., Pequignet, A.-C., Aucan, J., Boc, S. J., and Pollock, C. E.: Wave set-up over a Pacific Island fringing reef, J. Geophys. Res.-Oceans, 115, C12066, doi:10.1029/2010JC006455, 2010.

Yemm, S. P.: Field observation of set-up, M.S. Thesis, Naval Postgraduate School, USA, 45 pp., 2004 